DOI: https://doi.org/10.47405/mjssh.v7i1.1224

\begin{tabular}{|c|c|}
\hline${ }^{2}$ & Malaysian Journal of Social Sciences and Humanities (MJSSH) \\
\hline $\begin{array}{l}\text { Malaysian Journal of } \\
\text { Soccial Scicneces and }\end{array}$ & Volume 7, Issue 1, January 2022 \\
\hline (MJ-SSH) & e-ISSN : 2504-8562 \\
\hline & $\begin{array}{l}\text { Journal home page: } \\
\text { www.msocialsciences.com }\end{array}$ \\
\hline
\end{tabular}

\title{
Investigating Mental Health Among Malaysian University Students During Covid-19 Pandemic
}

\author{
Nor Azlili Hassan'1, Hasmiza Abdul Majeed², Jaslina Mohd Tajuddin³ ${ }^{3}$ Nor Hafizah Abdullah4, \\ Rahilah Ahmad ${ }^{5}$ \\ 1Faculty of Creative Industries, Universiti Tunku Abdul Rahman (UTAR), Malaysia \\ ${ }^{2}$ Faculty of Sports Science and Recreation, Universiti Teknologi MARA (UiTM), Malaysia \\ ${ }^{3}$ Faculty of Business, Accountancy, Communication and Hospitality Management, SEGi University, Malaysia \\ ${ }^{4}$ Faculty of Languages and Communication, Universiti Sultan Zainal Abidin (UNISZA), Malaysia \\ ${ }^{5}$ School of Marketing and Management, Asia Pacific University of Technology and Innovation, Malaysia \\ Correspondence: Nor Azlili Hassan (azlili@utar.edu.my)
}

\begin{abstract}
The COVID-19 pandemic and the lockdown have led to an increasing number of mental health issues in Malaysia. The demands of living during the pandemic have caused a rising number of university students to be diagnosed with depression, anxiety, stress and other mental health problems. A survey done by National Health and Morbidity 2015 found that the prevalence of mental health problems among adults in Malaysia has increased from $10.7 \%$ in 1996, to $11.2 \%$ in 2006, to $29.2 \%$ in 2015 . Moreover, one in 10 individuals in 2011 to one in five in 2016 cases reported are among Malaysian students. Thus, the study explores the prevalence of depression, anxiety and stress symptoms among university students in Malaysia during the COVID-19 pandemic. The study adopted the DASS-21 inventory to measure the mental health of the students during the pandemic COVID-19 that assesses the depression, anxiety and stress symptoms. Data obtained from the 355 Malaysian university students showed that most of the respondents were sometimes feeling depressed by having negative feelings (44.2\%)", and unable to become enthusiastic (44.5\%)", feeling anxious where they were close to panic $(33.8 \%)$ " and dryness of their mouth (31.5\%)", and feeling stressed where they found themselves getting agitated $(40.3 \%)$ " and difficult to relax (40.8\%)". The findings may suggest that further research is proposed for the inclusion of successful coping strategies used by the students during the COVID-19 pandemic. Research should also develop interventions and preventive strategies to address the mental health of university students.
\end{abstract}

Keywords: Mental health, depression, anxiety, stress, university students

\section{Introduction}

The occurrence of coronavirus disease 2019 (COVID-19), which started in China in December 2019, is a devastating tragedy that has spread across the entire world at the speed of light. It is critical to recognize stress symptoms resulting from the lockdowns and the disease itself. It is apparent that the unshakable psychological and social impacts of the pandemic are undeniable, and it is critical to take steps in developing strength and coping with such damaging consequences of a pandemic. As highlighted by Grubic et. al (2020), it is a timely call for studies investigating the impact of COVID-19 on students' mental health and the need for immediate interventions. 
Mental health issues are the foremost hindrance to academic success. Mental illness can affect students' motivation, concentration, and social interactions as they are the crucial factors for students to succeed in higher education (Unger, 2007). According to the United Nations Educational, Scientific, and Cultural Organization (UNESCO), the pandemic has disturbed the learning of more than one billion students in 129 countries around the world. Many universities worldwide have moved to online teaching and learning) via online platforms, further stimulating anxiety among the students. Studies on the effect of COVID-19 and lockdowns on college students in China reported significant undesirable effects on the students' psychological well-being and high levels of anxiety (Bao et. al, 2019; Cao et. al, 2020; Wang et. al, 2020).

Besides, the COVID-19 pandemic has brought into focus the mental health of various affected populations. It is known that the occurrence of epidemics highlights or creates new stressors including fear and worry for individuals or loved ones, limitations on physical movement and social activities due to quarantine, and sudden and drastic lifestyle changes. A recent review of virus outbreaks and pandemics recorded stressors such as infection fears, frustration, boredom, inadequate supplies, inadequate information, financial loss, and stigma. Much of the current literature on the psychological impacts of COVID-19 has emerged from the earliest hot spots in China. Although several studies have assessed mental health issues during epidemics, most studies have focused on health workers, patients, children, and the general population. Nelson et al (2020) have found levels of anxiety and depressive symptoms among general population samples in North America and Europe. However, except for a few studies, particularly from China (Wang, 2020), there is a scarce indication of the psychological or mental health effects of the current pandemic on college students, who are known to be a vulnerable population. Although the findings from these studies thus far meet on the mental health issues among college students, the contributing factors may not necessarily be generalizable to populations in other countries. As emphasized in multiple recent correspondences, there is an urgent need to assess the effects of the current pandemic on the mental health and well-being of college students (Holmes, 2020).

COVID-19 was first detected in Malaysia around January 2020. Cases recorded then were rather inadequate and mainly limited to tourists. Local outbreaks started to appear in March 2020 and the main cluster was connected to a religious gathering namely Tablighi Jamaat, in late February and early March, concluding in a sudden and sharp increase in local cases and those exported to neighbouring countries. Within weeks, Malaysia had registered the highest increasing number of COVID-19 infections in Asia. Legal action to mitigate the pandemic was promptly taken by the Malaysian government. On 18 March 2020, a nationwide Movement Control Order (MCO) or lockdown was declared which is targeted at controlling the viral outbreak. Quarantining of infected individuals and social distancing were implemented to restrict the virus' spread and reduce interactions with individuals infected with COVID-19. With the MCO, the Malaysian population was confined to a long period of social isolation. The extraordinary rules had significantly altered the lifestyles and social relationships between the community and had probably developed deep levels of anxiety along with the fear of contracting the infection. Although actions were taken primarily reduced the outbreak of COVID-19 in Malaysia, measures such as lockdowns, strict isolation, social distancing, online teaching and learning, and uncertainty and delays in the commencement of schools, colleges, and universities have significant implications on students' socio-psychological well-being and anxiety levels.

Lockdowns or quarantines are seen as necessary as protective measures for physical health, but prolonged burdens can be unfavourable. It is an unpleasant experience that can cause severe financial stress due to loss of employment, social disorders such as social withdrawal, cyberbullying, alcohol misuse, and addiction as well as mental health issues such as suicide attempts and depression (Reger et. al, 2020; Thunstrom, 2020). Even during the SARS outbreak, quarantine was linked to high rates of depression (31.2\%) and anxiety (28.9\%). Similarly, high anxiety was detected throughout the 2009 H1N1 pandemic and those in quarantine experienced monotony, loneliness, irritation, worsening anxiety, and mental distress. COVID-19 has been repeatedly considered as a killer virus, mainly on social media which has prolonged feelings of perceived threats and uncertainty. Compulsory 14-day quarantines and tracking as part of the public health protocols during the pandemic further increase individual's anxiety based on the impacts of infection and stigma. The lockdown stressors involve 
separation from family and friends, loss of independence, fears about the virus's spread, lockdown length, hatred, repetitious lifestyle, a potential shortage of essential goods, lack of accurate information, financial loss, and stigma.

To date, several studies have been conducted on the effects of the COVID-19 pandemic and lockdowns from the public health perspective. Most of the research has been conducted in China and Western countries, mainly among the general population, healthcare workers, and medical students (Gao et. al, 2020; Casagrande et. al, 2020; Roy et. al, 2020; Yang et. al, 2020; Zandifar, 2020; Zhang et. al, 2020; Lazarus, 1984). Few such studies have been performed in Malaysia. Thus, this study hopes to extend the existing literature by empirically evaluating the impacts of the COVID-19 pandemic and the subsequent lockdowns on the depression, anxiety and stress among Malaysian university students, during the Covid-19 pandemic and lockdown, between January to May 2021. This study explores the prevalence of depression, anxiety and stress symptoms among university students in Malaysia during the COVID-19 pandemic. We hope the findings of this study could assist universities in Malaysia in forming a theoretical basis for determining psychological well-being and identifying evidence-based psychological intervention practices to assist the students in times of similar pandemics in the future. The study should also provide guidelines for policymakers on possible mechanisms to balance the impacts of depression, anxiety and stress on university students during such health crises.

\section{Literature Review}

One of the leading health issues around the world is human mental health. Although there is no single common definition for the term mental health, the term may refer to a broader concept that includes both positive mental health and mental health problems (WHO, 2005). Lately, the incidence of mental health problems is upsetting and affecting all walks of life. It was found that approximately 970 million people had a mental health disorder (MHD) in 2017 (G.B.D. Disease Injury Incidence Prevalence Collaborators, 2018). A study by Vigo et. al (2016) reported that globally, one in every three individuals are found to suffer from a mental illness that distracts the state of their mental health. The incidences of depressive, anxiety and stressful symptoms may reflect the idea of one's mental health condition.

Stress is a particular relationship between the person and the environment that the person considers to be taxing or exceeding his or her resources and putting his or her well-being at risk (Lazarus et. al, 1984). Thus, stress is best viewed as an interpretative paradigm between the stressors and the individual's psychological reactions. Anxiety, being a subcategory of psychological impacts, has attracted less attention, although it is as widespread and conceivably as crippling as depression. Anxiety can be powered by uncertainty and by fears of the risk of harm to self or others. Anxiety is still undiagnosed and under-treated in the global context (Kroenke, 2007). In addition to intense feelings of fear or panic (Brawman-Mintzer, 2004), anxious individuals may also experience other physiological symptoms, such as feeling weak, fainting, pain or nausea, shivers, rapid breathing and so forth (Testa et. al, 2013). Anxiety impairs focus and concentration (Eysenck, 2007), memory (Moran 2016), and visual-motor skills (Runswick et al., 2017).

This prevalence of mental health is still growing, especially during this pandemic COVID-19 which is also affecting our youth and students. Chang et. al (2021) suggested that the prevalence of anxiety and depressive symptoms in worldwide college students during the COVID-19 pandemic is relatively high. Oketch-Oboth and Odiemo (2018) in their study showed that $64.4 \%$ of their respondents (university students) experienced between moderate to high levels of stress while just over a third $(35.6 \%)$ reported low-stress levels. A study among Malaysian university students found that around $30 \%$ of the students were reported to experience some level of anxiety due to the COVID-19 pandemic in their country (Kamaludin et al., 2020). Previously, the prevalence of stress among medical students was shown to be high and academic-related problems were reported to be the major stressor among these medical students (Yusoff, Abdul Rahim, and Yaacob, 2010). These incidences of depressive, anxiety and stressful symptoms of university students must be given greater attention and proper measurement. 
If they are not well treated, it may lead to numerous negative consequences such as a decrease in the students' academic performance as well as leading to poor health conditions of the students.

Odriozola-González et al. (2020) studied the psychological well-being of Spanish university students during the COVID-19 pandemic. The study was conducted from March 28 to 4 April 2020, after the lockdown in Spain due to the COVID-19 pandemic. In the sample, 34.19\% of respondents showed moderate to extremely severe depression symptoms; $21.34 \%$ showed extremely severe anxiety symptoms and $28.14 \%$ exhibited moderate to extremely severe stress symptoms. The occurrence of anxiety was higher among students compared to that among the general population. Several stressors have been identified as key factors affecting the students' anxiety and psychological well-being such as a parent or associate being infected by COVID-19, financial issues and their effects on daily life, educational interruptions (Cao et al 2020), effects of the disease on education and potential jobs (Wang et. al, 2020, Cornine, 2020); as well as sensational programs or social media and inaccurate news reports (Ayittey et. al, 2020). Other stressors include students' place of residence, family income stability (Peng et. al, 2012), parents' psychological status (Gentili, 2020), reduced social interactions (Xiao et. al, 2020), increased number of new cases and affected provinces (Bao et al 2020), and the imposition of travel bans affecting daily life (Tang et. al, 2020).

Specifically, early literature has recorded the negative influence of pandemics on students' psychological well-being (Mosley et. al, 1994), which has led to acute depression and anxiety (Aktekin, 2001). Cao et. al (2020) investigated the psychological impact on university students in China during the COVID-19 pandemic. Out of 7143 students studied, $0.9 \%$ had severe anxiety, $2.7 \%$ had moderate anxiety, and $21.3 \%$ had mild anxiety. Then, the study by Wang et al (2020) on 1210 students from 194 cities in China, revealed that 53.8\% of respondents had severe to moderate psychological impact, with female students being associated with greater psychological impacts. As suggested in previous studies (Wang et. al, 2020; Bayram, 2008; Auerbach et. al, 2016: Bruffaerts et. al, 2018) also said that worsened uncertainty and its bearings on students' academic progress could influence students' psychological well-being. Hence, to better understand the mental health of Malaysian university students during this COVID-19 pandemic, this study was conducted to investigate the prevalence of depressive, anxiety and stress symptoms among those university students. It is important to identify those students with these issues so that the appropriate measure can be taken to reduce the condition before it gets worse.

\section{Methodology}

The current study is aimed at exploring the mental health and gender of university students at the time of Covid 19. The study was conducted as a cross-sectional survey that used a quantitative approach. The questionnaire was constructed using Depression Anxiety Stress Scale (DASS 21) and Self Efficacy Scale as found through literature review. In this study, convenience sampling is used, and researchers have distributed the questionnaires to 355 university students from three private universities and three public universities around Malaysia as study respondents. Questionnaires were distributed online via Google Forms as Malaysia is currently under Movement Control Order (MCO) due to Covid 19. The data obtained were then analysed using Statistical Package for Social Sciences (SPSS 21).

\section{Findings and Analysis}

In this study, a total of 355 responses were received and found to be usable. The demographic characteristics of the respondents are shown in Table 1. Among the 355 respondents, $55.2 \%$ were females, the majority were in the ethnic group of Malays (47.6\%) and half were Muslims $(52.7 \%)$. Proportions of students from public and private universities were $56.6 \%$ and $43.4 \%$. In terms of field of study, about $58.9 \%$ were enrolled in Art streams and 33\% of the respondents were pursuing in their first year of study. At the time of data collection, almost all the universities were on a virtual mode of delivery. Most (84.4\%) of the students in this study stayed with their parents and have two or three 
DOI: https://doi.org/10.47405/mjssh.v7i1.1224

siblings (21\%). 69\% of the respondents were living in urban areas and falling in the category of B40 families $(47.9 \%)$.

Table 1: Demographic Characteristics of the Respondents $(\mathrm{N}=355)$

\begin{tabular}{|c|c|c|}
\hline Variable & Percentage & Frequency \\
\hline \multicolumn{3}{|l|}{ Gender } \\
\hline Male & 44.8 & 159 \\
\hline Female & 55.2 & 196 \\
\hline \multicolumn{3}{|l|}{ Religion } \\
\hline Islam & 52.7 & 187 \\
\hline Buddha & 31.8 & 113 \\
\hline Christian & 9.6 & 34 \\
\hline Hindu & 2.3 & 8 \\
\hline Others & 3.7 & 13 \\
\hline \multicolumn{3}{|l|}{ Ethnic } \\
\hline Malay & 47.6 & 169 \\
\hline Chinese & 41.4 & 147 \\
\hline Indian & 2.5 & 9 \\
\hline Others & 8.5 & 30 \\
\hline \multicolumn{3}{|l|}{ Number of Siblings } \\
\hline 1 & 13.2 & 47 \\
\hline 2 & 21.4 & 76 \\
\hline 3 & 21.1 & 75 \\
\hline 4 & 19.4 & 69 \\
\hline 5 & 10.4 & 37 \\
\hline More than 5 & 14.4 & 51 \\
\hline \multicolumn{3}{|l|}{ Family Status } \\
\hline Stay with guardian & 2.5 & 9 \\
\hline Stay with parents (both mother and father) & 84.4 & 301 \\
\hline Stay with a single parent (mother or father) & 12.7 & 45 \\
\hline \multicolumn{3}{|l|}{ Place of Residence } \\
\hline Rural area & 31.0 & 110 \\
\hline Urban area & 69.0 & 245 \\
\hline \multicolumn{3}{|l|}{ Parents' Socio-Economic Status } \\
\hline B40 & 47.9 & 170 \\
\hline M40 & 42.3 & 150 \\
\hline $\mathrm{T} 20$ & 9.9 & 35 \\
\hline \multicolumn{3}{|l|}{ Type of University } \\
\hline Public University & 56.6 & 201 \\
\hline Private University & 43.4 & 154 \\
\hline \multicolumn{3}{|l|}{ Year of Study } \\
\hline Year 1 & 33.0 & 117 \\
\hline Year 2 & 32.1 & 114 \\
\hline Year 3 & 31.0 & 110 \\
\hline Year 4 & 2.3 & 8 \\
\hline Others & 1.7 & 6 \\
\hline \multicolumn{3}{|l|}{ Field of Study } \\
\hline Arts Stream & 58.9 & 209 \\
\hline Science Stream & 41.1 & 146 \\
\hline
\end{tabular}


The Independent student's T-test statistical analysis was carried out to compare the level of depression, anxiety and stress among the Malaysian university students. Out of the 21 items studied in DASS, 7 items corresponded to depression, 7 items corresponded to anxiety and 7 items corresponded to stress. The depression scale assesses dysphoria, hopelessness, devaluation of life, self-deprecation, lack of interest or involvement, anhedonia, and inertia; the anxiety scale assesses autonomic arousal, skeletal muscle effects, situational anxiety, and subjective experience of anxious affect while the stress scale is sensitive to levels of chronic non-specific arousal. It also measures difficulty relaxing, nervous arousal, and being easily agitated, irritable, and impatient.

This study examined depression, anxiety and stress among university students in Malaysia during the COVID-19 pandemic and the lockdown period between January and May 2021. Based on DASS-21, the majority of the respondents experienced mild levels of depression and anxiety and normal levels of stress. DASS-21 indicated that it is a reliable instrument that can be applied in exploring depression, anxiety and stress symptoms among university students. Generally, it could even be that Malaysian people report being anxious and depressed, at the same time they can still be satisfied and happy with their lives. Most of the respondents were sometimes feeling depressed in the items such as "I couldn't seem to experience any positive feeling at all (44.2\%)", and "I was unable to become enthusiastic about anything (44.5\%)", feeling anxious in the items such as" I felt I was close to panic (33.8\%)" and "I was aware of dryness of my mouth (31.5\%)", and feeling stressed in the items such as "I found it hard to wind down (42.5\%), "I found myself getting agitated (40.3\%" and "I found it difficult to relax (40.8\%)". Difficulty in concentrating and relaxing, frequently expressed by the respondents, has previously been shown to affect students' confidence in themselves (Martin, 2010) which has led to the correlation to increased stress and mental health (Zuckerman, 1989). Although the respondents specifically mentioned several effects such as negative feelings, no enthusiasm, feeling panic and dryness as well as getting agitated and difficult to relax, other outcomes may also act as contributors to depressive thoughts and suicidal ideation. Both feeling panic and difficulty relaxing are associated with depression (Acharya, 2018). It could be that Malaysian students are less tolerant of situations where they are not in control. The results are recorded in Table 2.

Table 2 Depression, Anxiety and Stress Level

\begin{tabular}{|c|c|c|c|c|c|}
\hline No. & Items & $\begin{array}{l}\text { NEVER } \\
\quad(0)\end{array}$ & $\begin{array}{l}\text { SOMETIMES } \\
\text { (1) }\end{array}$ & $\begin{array}{l}\text { OFTEN } \\
\text { (2) }\end{array}$ & $\begin{array}{l}\text { ALMOST } \\
\text { ALWAYS } \\
\text { (3) }\end{array}$ \\
\hline \multicolumn{6}{|c|}{ DEPRESSION LEVEL } \\
\hline 1. & $\begin{array}{l}\text { I couldn't seem to experience any } \\
\text { positive feeling at all }\end{array}$ & $103(29 \%)$ & $157(44.2 \%)$ & $78(22 \%)$ & $17(4.8 \%)$ \\
\hline 2. & $\begin{array}{l}\text { I found it difficult to work up the } \\
\text { initiative to do things }\end{array}$ & $65(18.3 \%)$ & $129(36.3 \%)$ & $102(28.7 \%)$ & $59(16.6 \%)$ \\
\hline 3. & $\begin{array}{l}\text { I felt that I had nothing to look } \\
\text { forward to }\end{array}$ & $117(33 \%)$ & $143(40.3 \%)$ & $64(18 \%)$ & $31(8.7 \%)$ \\
\hline 4. & I felt downhearted and blue & $106(29.9 \%)$ & $130(36.6 \%)$ & $85(23.9 \%)$ & $34(9.6 \%)$ \\
\hline 5. & $\begin{array}{l}\text { I was unable to become enthusiastic } \\
\text { about anything }\end{array}$ & $115(32.4 \%)$ & $158(44.5 \%)$ & $57(161 \%)$ & $25(7 \%)$ \\
\hline 6. & I felt I wasn't worth much as a person & $135(38 \%)$ & $113(31.8 \%)$ & $62(17.5 \%)$ & $45(12.7 \%)$ \\
\hline 7. & I felt that life was meaningless & $168(47.3 \%)$ & $102(28.7 \%)$ & $53(14.9 \%)$ & $32(9 \%)$ \\
\hline \multicolumn{6}{|c|}{ ANXIETY LEVEL } \\
\hline 8. & I was aware of dryness of my mouth & $70(19.7 \%)$ & $112(31.5 \%)$ & $115(32.4 \%)$ & $58(16.3 \%)$ \\
\hline 9. & $\begin{array}{l}\text { I experienced breathing difficulty (eg, } \\
\text { excessively rapid breathing, } \\
\text { breathlessness in the absence of } \\
\text { physical exertion) }\end{array}$ & $158(44.5 \%)$ & $120(33.8 \%)$ & $62(17.5 \%)$ & $15(4.2 \%)$ \\
\hline 10 & $\begin{array}{l}\text { I experienced trembling (eg, in the } \\
\text { hands) }\end{array}$ & $139(39.2 \%)$ & $122(34.4 \%)$ & $66(18.6 \%)$ & $28(7.9 \%)$ \\
\hline 11 & $\begin{array}{l}\text { I was worried about situations in } \\
\text { which I might panic and make a fool } \\
\text { of myself }\end{array}$ & $75(21.1 \%)$ & $105(29.6 \%)$ & $93(26.2 \%)$ & $82(23.1 \%)$ \\
\hline
\end{tabular}


DOI: https://doi.org/10.47405/mjssh.v7i1.1224

\begin{tabular}{|c|c|c|c|c|c|}
\hline 12 & I felt I was close to panic & $119(33.5 \%)$ & $120(33.8 \%)$ & $87(24.5 \%)$ & $29(8.2 \%)$ \\
\hline 13 & $\begin{array}{l}\text { I was aware of the action of my heart } \\
\text { in the absence of physicalexertion } \\
\text { (eg, sense of heart rate increase, heart } \\
\text { missing a beat) }\end{array}$ & $124(34.9 \%)$ & $111(31.3 \%)$ & $84(23.7 \%)$ & $36(10.1 \%)$ \\
\hline 14 & I felt scared without any good reason & $\begin{array}{l}132(37.2 \% \\
\text { STRESS LEVEI }\end{array}$ & $109(30.7 \%)$ & $71(20 \%)$ & $43(12.1 \%)$ \\
\hline 15 & I found it hard to wind down & $52(14.6 \%)$ & $151(42.5 \%)$ & $127(35.8 \%)$ & $25(7 \%)$ \\
\hline 16 & I tended to over-react to situations & $86(24.2 \%)$ & $131(36.9 \%)$ & $88(24.8 \%)$ & $50(14.1 \%)$ \\
\hline 17 & $\begin{array}{l}\text { I felt that I was using a lot of nervous } \\
\text { energy }\end{array}$ & $86(24.2 \%)$ & $121(34.1 \%)$ & $102(28.7 \%)$ & $46(13 \%)$ \\
\hline 18 & I found myself getting agitated & $105(29.6 \%)$ & $143(40.3 \%)$ & $79(22.3 \%)$ & $28(7.9 \%)$ \\
\hline 19 & I found it difficult to relax & $107(30.1 \%)$ & $145(40.8 \%)$ & $77(21.7 \%)$ & $26(7.3 \%)$ \\
\hline 20 & $\begin{array}{l}\text { I was intolerant of anything that kept } \\
\text { me from getting on with what I was } \\
\text { doing }\end{array}$ & $98(27.6)$ & $140(39.4 \%)$ & $86(24.2 \%)$ & $31(8.7 \%)$ \\
\hline 21 & I felt that I was rather touchy & $111(31.3 \%)$ & $123(34.6 \%)$ & $73(20.6 \%)$ & $48(13.5 \%)$ \\
\hline
\end{tabular}

University students comprise a population that is considered vulnerable to mental health issues. By conducting the online survey during the pandemic, this study found most of the participants were sometimes experiencing increased depression, anxiety and stress due to Covid-19. The most highlighted stressors were predominantly due to online classes, and uncertainty about the future due to COVID-19 and lockdowns. The students faced difficult tasks in terms of technological infrastructure, mainly poor internet connection. It is also shocking to note that some students attended six to eight hours of daily online classes using their mobile phones, which further contributed to insurmountable stress and health issues. In addition, the overwhelming expectations from their lecturers, with multiple assignments and no flexible deadlines, added to the students' anxiety. Uncertainty regarding their exams, completion of their semester and graduation, and the need to juggle household chores and take care of siblings while simultaneously attending online classes had a huge impact on their anxiety levels. Students, especially those graduating, were also distressed because they were helpless in their plans to launch their careers. As stated by Fransen (2015), people should feel that "everyone is in this together."

Higher education institutions can play a fundamental role in assisting students to cope with such anxieties. New guidelines for counselling are required (Bao et. al, 2020; Yang et. al, 2020; Xiang et. al, 2020). Universities should set priorities in developing digital psychological interventions, such as apps and online programs, alongside other services such as text messages, chatlines, forums, and phone calls (Holmes, 2020). Awareness of the presence of such interventions should be communicated to the student population. Universities should also provide psychological services, either face to face or remotely, as they will mitigate the emotional and mental impacts on students. It is crucial to be constantly in touch with the students. Universities ought to embark on structured programs to reduce anxiety, such as life skills training and mindfulness therapy, which have been validated to reduce anxiety levels. Equally important is for universities to re-examine their curricula, learning outcomes, and assessment methods for the courses and programs taught online as they should be distinguished from those meant for face-to-face teaching mode.

\section{Conclusion}

The empirical evidence from this study indicates that most of the respondents were sometimes feeling depressed, anxious and stressed respectively during the COVID-19 pandemic and lockdown period. The findings revealed lower levels of depression, anxiety and stress symptoms among Malaysian university students. As in all surveys using questionnaires, there is always the uncertainty of whether the respondents answered the questions honestly. In this study, data were collected in January and May 2021. By this time, most students had already moved back to their family homes as the university residences were closed. The anxiety levels of the students could have been different if the data had been collected at the peak period of COVID-19, which was in mid-March 2020. 
Most importantly, all comprehensive teaching and learning strategies during pandemics should be reflected immediately, as this study confirms that online teaching and learning has contributed to significant anxiety among students. Policies and standard operating procedures (SOPs) should be in place to educate students on the causes and consequences of pandemics in a simplified, clear, and supportive manner without causing undue anxiety and distress. Communicating correct and timely information through the right channels is important. Efforts should also be focused on discovering innovative methods of upholding social attachment amongst students while still complying with public health guidelines for curbing the spread of the pandemic. Strict measures and penalties should be enforced against dishonest individuals to curb false information via social media, as this seems to be a chief source of undue anxiety amongst students.

Malaysia is a developing country where $40 \%$ of the population lives in poverty. Overall, academic challenges, unemployment, high family expectations, political conditions and poor living environment do not contribute to depression, anxiety and stress symptoms among Malaysian students during the COVID-19 pandemic. However, further research is proposed for the inclusion of successful coping strategies used by the students during the COVID-19 pandemic. Research should also be concentrated toward teaching, learning, and assessment methods in the "new normal" space, which can have the dual benefit of maximizing learning outcomes and minimizing anxiety and adverse psychological impacts among students. Lastly, research focusing on the use of digital technology and psychological artificial intelligence solutions to manage anxiety levels of university students should be strengthened. There is a clear call for all stakeholders in the education industry to recognize the need for an immediate and holistic policy to identify and manage the psychological impact of COVID-19 or any future pandemics on university students. Thus, both higher education institutions and the relevant ministries at a stronger level play a crucial role.

\section{References}

Acharya L, Jin L. \& Collins W. (2018). College life is stressful today - emerging stressors and depressive symptoms in college students. Journal of American College Health, 66(7):655-664.

Aktekin, M., Karaman, T., Senol, Y.Y., Erdem, S., Erengin, H. \& Akaydin, M. (2001). Anxiety, depression and stressful life events among medical students: A prospective study in Antalya, Turkey. Medical Education, 35, 12-17.

Auerbach, R.P., Alonso, J., Axinn, W.G., Cuijpers, P., Ebert, D.D., Green, J.G. \& Nock, M.K. (2016). Mental disorders among college students in the World Health Organization world mental health surveys. Psychological Medicine, 46, 2955-2970.

Ayittey, F.K., Ayittey, M.K., Chiwero, N.B., Kamasah, J.S. \& Dzuvor, C. (2020). Economic impacts of Wuhan 2019-nCoV in China and the world. Journal of Medical Virology, 92,473-475.

Bao, Y., Sun, Y., Meng, S., Shi, J. \& Lu, L. (2020). 2019-nCoV epidemic: Address mental health care to empower society. The Lancet 395: e37-e38.

Bayram, N. \& Bilgel, N. (2008). The prevalence and socio-demographic correlations of depression, anxiety and stress among a group of university students. Social Psychiatry and Psychiatric Epidemiology, 43, 667-672.

Brawman-Mintzer, O. \& Yonkers, K.A. (2004). New trends in the treatment of anxiety disorders. CNS Spectrums 9: 19-27.

Bruffaerts, R., Mortier, P., Kiekens, G., Auerbach, R.P., Cuijpers, P., Demyttenaere, K. \& Kessler, R.C. 2018. Mental health problems in college freshmen: Prevalence and academic functioning. Journal of Affective Disorders, 225, 97-103.

Cao, W., Fang, Z., Hou, G., Han, M., Xu, X., Dong, J. \& Zheng, J. (2020). The psychological impact of the COVID-19 epidemic on college students in China. Psychiatry Research, 287, 112934.

Casagrande, M., Favieri, F., Tambelli, R. \& Forte, G. (2020). The enemy who sealed the world: Effects quarantine due to the COVID-19 on sleep quality, anxiety, and psychological distress in the Italian population. Sleep Medicine. 2020. 
Chang, J. J., Ji, Y., Li, Y. H., Pan, H. F., \& Su, P. Y. (2021). Prevalence of anxiety symptom and depressive symptom among college students during COVID-19 pandemic: A meta-analysis. Journal of Affective Disorders, 242-254.

Collaborators, G. B. D. (2018). Global, regional, and national incidence, prevalence, and years lived with disability for 354 diseases and injuries for 195 countries and territories, 1990-2017: a systematic analysis for the Global Burden of Disease Study 2017.

Cornine, A. (2020). Reducing nursing student anxiety in the clinical setting: An integrative review. Nursing Education Perspectives, 41, 229-234.

Eysenck, M.W., Derakshan, N.S.R. \& Calvo, M.G. (2007). Anxiety and cognitive performance: Attentional control theory. Emotion, 7, 336-353.

Fransen, K., Haslam, S.A., Steffens, N.K., Vanbeselaere, N., De Cuyper, B. \& Boen, F. (2015). Believing in "us": Exploring leaders' capacity to enhance team confidence and performance by building a sense of shared social identity. Journal of Experimental Psychology: Applied, 21, 89.

Gao, J., Zheng, P., Jia, Y., Chen, H., Mao, Y., Chen, S. \& Dai, J. (2020). Mental health problems and social media exposure during COVID-19 outbreak. PLoS ONE, 215: e0231924.

Gentili, D., Bardin, A., Ros, E., Piovesan, C., Ramigni, M., Dalmanzio, M., Dettori, M., Filia, A. \& Cinquetti, S. (2020). Impact of communication measures implemented during a school tuberculosis outbreak on risk perception among parents and school staff, Italy, 2019. International Journal of Environmental Research and Public Health, 17, 911.

Grubic, N., Badovinac, S. \& Johri, A.M. (2020). Student mental health in the midst of the COVID-19 pandemic: A call for further research and immediate solutions. International Journal of Social Psychiatry, 66, 517-518.

Holmes, E.A., O’Connor, R.C., Perry, V.H., Tracey, I., Wessely, S., Arseneault, L. \& Ford, T. (2020). Multidisciplinary research priorities for the COVID-19 pandemic: A call for action for mental health science. Lancet Psychiatry, 7, 547-560.

Kamaludin, K., Chinna, K., Sundarasen, S., Khoshaim, H. B., Nurunnabi, M., Baloch, G. M., Sukayt, A., \& Hossain, S. (2020). Coping with COVID-19 and movement control order (MCO): experiences of university students in Malaysia. Heliyon, 6(11), e05339. https://doi.org/10.1016/j.heliyon.2020.e05339.

Kroenke, K., Spitzer, R.L., Williams, J.B., Monahan, P.O. \& Lowe, B. (2007). Anxiety disorders in primary care: Prevalence, impairment, comorbidity, and detection. Annals of Internal Medicine, 146, 317-325.

Lazarus, R.S. \& Folkman, S. (1984). Stress, Appraisal, and Coping. Springer Publishing Company: New York, NY, USA.

Martin J.M. (2010). Stigma and student mental health in higher education. Higher Education Research \& Development, 29(3), 259-274.

Moran, T.P. (2016). Anxiety and working memory capacity: A meta-analysis and narrative review. Psychological Bulletin Journal, 142, 831-864.

Mosley, T.H., Perrin, S.G., Neral, S.M., Dubbert, P.M., Grothues, C.A. \& Pinto, B.M. (1994). Stress, coping, and well-being among third-year medical students. Academic Medicine, 69, 765-767.

Nelson B, Pettitt A, Flannery J. \& Allen N. (2020). Rapid assessment of psychological and epidemiological correlates of COVID-19 concern, financial strain, and health-related behavior change in a large online sample. International Journal of Methods in Psychiatric Research, 21(3), 169-184.

Odriozola-González, P., Planchuelo-Gómez, Á., Irurtia, M.J. \& de Luis-García, R. (2020). Psychological effects of the COVID-19 outbreak and lockdown among students and workers of a Spanish university. Journal of Psychiatry Research, 290, 113108.

Oketch-Oboth, Josiah \& Odiemo, Luke. (2018). The Relationship Between Levels of Stress and Academic Performance Among University of Nairobi Students. International Journal of Learning and Development, 8. 10.5296/ijld.v8i4.13840.

Peng, L., Zhang, J., Li, M., Li, P., Zhang, Y., Zuo, X., Miao, Y. \& Xu, Y. (2012). Negative life events and mental health of Chinese medical students: The effect of resilience, personality and social support. Journal of Psychiatric Research, 196, 138-141.

Reger, M.A., Stanley, I.H. \& Joiner, T.E. (2020). Suicide mortality and coronavirus disease 2019-A perfect storm? JAMA Psychiatry. 
Roy, D., Tripathy, S., Kar, S.K., Sharma, N., Verma, S.K. \& Kaushal, V. (2020). Study of knowledge, attitude, anxiety \& perceived mental healthcare need in Indian population during COVID-19 pandemic. Asian Journal of Psychiatry, 102083.

Runswick, O.R., Roca, A., Williams, A.M., Bezodis, N.E. \& North, J.S. (2018). The effects of anxiety and situation-specific context on perceptual-motor skill: A multi-level investigation. Psychological Research, 82, 708-719.

Tang, B., Wang, X., Li, Q., Bragazzi, N.L., Tang, S., Xiao, Y. \& Wu, J. (2020). Estimation of the transmission risk of the 2019-Nov and its implication for public health interventions. Journal of Clinical Medicine, 9, 462.

Testa, A., Giannuzzi, R., Sollazzo, F., Petrongolo, L., Bernardini, L. \& Daini, (2013). S. Psychiatric emergencies (part I): Psychiatric disorders causing organic symptoms. European Review for Medical and Pharmacological Sciences, 17, 55-64.

Thunström, L., Newbold, S.C., Finnoff, D., Ashworth, M. \& Shogren, J.F. (2020). The benefits and costs of using social distancing to flatten the curve for COVID-19. Journal of Benefit Cost Analysis, $1-27$.

Unger K. (2007). Handbook on Supported Education: Providing Services for Students With Psychiatric Disabilities. Charleston, SC: BookSurge Publishing.

Vigo, D., Thornicroft, G., \& Atun, R. 2016. Estimating the true global burden of mental illness. The Lancet Psychiatry, 3(2), 171-178.

Wang, G., Zhang, Y., Zhao, J., Zhang, J. \& Jiang, F. (2020). Mitigate the effects of home confinement on children during the COVID-19 outbreak. Lancet, 395, 945-947.

Wang C. \& Zhao H. (2020). The impact of COVID-19 on anxiety in Chinese university students. Frontiers in Psychology, 11,1168.

WHO, E. (2005). Mental health: Facing the challenges, building solutions. In Report from the WHO European Ministerial Conference. WHO.

Yang, Y., Li, W., Zhang, Q., Zhang, L., Cheung, T. \& Xiang, Y.T. (2020). Mental health services for older adults in China during the COVID-19 outbreak. Lancet Psychiatry, 7, e19.

Xiao, H., Zhang, Y., Kong, D., Li, S. \& Yang, N. (2020). The effects of social support on sleep quality of medical staff treating patients with coronavirus disease 2019 (COVID-19) in January and February 2020 in China. Medical Science Monitor: International Medical Journal of Experimental and Clinical Research, 26, e923549.

Yusoff, M. S., Abdul Rahim, A. F., \& Yaacob, M. J. (2010). Prevalence and Sources of Stress among Universiti Sains Malaysia Medical Students. The Malaysian Journal of Medical Sciences: MJMS, 17(1): 30-37.

Zandifar, A. \& Badrfam, R. (2020). Iranian mental health during the COVID-19 epidemic. Asian Journal of Psychiatry, 51.

Zhang, J., Wu, W., Zhao, X. \& Zhang, W. (2020). Recommended psychological crisis intervention response to the 2019 novel coronavirus pneumonia outbreak in China: A model of West China Hospital. Precision Clinical Medicine, 3, 3-8.

Zuckerman D.M. (1989). Stress, self-esteem, and mental health: how does gender make a difference?. Sex Roles, 20(7-8), 429-444. 